\title{
PENGETAHUAN IBU RUMAH TANGGA TENTANG HIV/ AIDS DI RT 01 RW 01 DUSUN PUCUNG LOR KECAMATAN NGANTRU KABUPATEN TULUNGAGUNG
}

Aprilia Nurtika Sari ${ }^{1}$

${ }^{1}$ Akademi Kebidanan Dharma Husada Kediri Jawa Timur

\begin{abstract}
Abstrak
HIV (Human Immunodeficiency Virus)/ AIDS (Acquired Immuno Deficiency Syndrome) merupakan penyakit menular yang masih menjadi masalah utama di Indonesia. Namun demikian, dalam kehidupan sehari-hari, topik mengenai HIV/ AIDS masih menjadi tabu untuk dibicarakan. Padahal, ketidaktahuan merupakan awal dari bahaya yang dapat mengancam jiwa karena HIV/AIDS merupakan penyakit yang menular. Siapapun dapat tertular HIV/AIDS jika tidak melindungi diri dengan benar. Tujuan dari penelitian ini adalah mengetahui gambaran pengetahuan ibu rumah tangga tentang HIV/AIDS.

Penelitian ini merupakan penelitian deskriptif dengan pendekatan cross sectional. Sampel yang digunakan adalah ibu rumah tangga sejumlah 50 orang yang didapatkan dengan teknik accidental sampling. Penelitian dilakukan pada bulan Maret 2018 di RT 01 RW 01 Dusun Pucung Lor Kecamatan Ngantru Kabupaten Tulungagung. Pengumpulan data menggunakan kuesioner. Data dianalisis dengan persentase.

Hasil penelitian menunjukkan pengetahuan ibu rumah tangga tentang HIV/AIDS termasuk kategori cukup, yaitu 23 responden (46\%), dan 27 responden (54\%) termasuk kategori kurang. Berdasarkan karakteristik responden, sebagian besar adalah ibu rumah tangga yang berusia lebih dari 35 tahun sebanyak $30(60 \%)$ responden, dan tingkat pendidikan SMP sebanyak $26(52 \%)$ responden.

Simpulan dari penelitian ini adalah sebagian besar ibu rumah tangga memiliki pengetahuan yang kurang tentang HIV/AIDS. Petugas kesehatan perlu memaksimalkan upaya dalam memberikan penyuluhan - penyuluhan kesehatan khususnya mengenai HIV/AIDS kepada ibu rumah tangga. Sehingga mereka mempunyai pengetahuan yang baik dan mampu mencegah penularan HIV/AIDS.
\end{abstract}

Kata kunci : Pengetahuan, Ibu Rumah Tangga, HIV/AIDS

\begin{tabular}{lllllllllll}
\hline Korespondensi: J1. Argowilis & RT 002/RW & 005 & Semen & Kediri & Jawa & Timur & HP: & 08563651556 & Email: \\
& aprilia.ns0486@gmail.com
\end{tabular} 


\section{Pendahuluan}

HIV adalah sejenis virus yang menginfeksi sel darah putih, yang menyebabkan kekebalan tubuh penderita menurun. AIDS adalah sekumpulan gejala penyakit yang timbul akibat menurunnya sistem kekebalan tubuh akibat infeksi HIV (Kemenkes RI, 2014). HIV/AIDS merupakan salah satu penyakit yang penyebarannya paling banyak di seluruh dunia. Pada tahun 2016, ada sekitar 1,8 juta kasus HIV baru. Jumlah tersebut mengalami penurunan dibandingkan tahun 2015, dimana jumlah kasus HIV baru adalah 2,1 juta orang (UNAIDS, 2018).

Di Indonesia, HIV/AIDS ditemukan pertama kali di provinsi Bali pada tahun 1987 (Kemenkes RI, 2014). Pada tahun 2017 ditemukan 4.555 kasus baru AIDS dan 33.660 kasus baru HIV di Indonesia (Kemenkes RI, 2018).

Berdasarkan data Kemenkes RI tahun 2017, provinsi Jawa Timur merupakan provinsi urutan pertama yang memiliki jumlah infeksi HIV terbesar, yaitu 8.204 kasus dan provinsi urutan keempat dengan kasus AIDS terbanyak, yaitu 741 kasus (Kemenkes RI, 2018). Menurut jenis pekerjaan, penderita AIDS di Indonesia paling banyak berasal dari kelompok ibu rumah tangga. Hingga September 2014, jumlah kumulatif AIDS pada ibu rumah tangga yang dilaporkan mencapai 6.539 kasus (Kemenkes RI, 2018).

Perempuan dan remaja putri ternyata lebih rentan tertular HIV. Hasil studi menunjukkan bahwa kemungkinan perempuan dan remaja putri tertular HIV 2,5 kali dibandingkan laki-laki dan remaja putra. UNAIDS melaporkan bahwa $67 \%$ kasus baru HIV dan AIDS di negara berkembang ada pada kalangan usia muda ( 15-24 tahun). Dari jumlah tersebut, $64 \%$ adalah perempuan dan remaja putri usia 15-24 tahun. Kerentanan perempuan dan remaja putri untuk tertular umumnya disebabkan karena kurangnya pengetahuan dan informasi mereka tentang HIV/AIDS ataupun kurangnya akses untuk mendapatkan layanan pencegahan HIV (Kementerian Negara Pemberdayaan Perempuan RI, 2008).

Penelitian yang dilakukan oleh Abhinaja \& Astuti (2013) di Kelurahan Sanur, Kecamatan Denpasar Selatan, Kota Denpasar diperoleh hasil bahwa pengetahuan tentang HIV/AIDS dari 87 responden ibu rumah tangga, 18 (20,7\%) dikategorikan tinggi, pengetahuan sedang 47 $(54,0 \%)$, dan pengetahuan rendah $22(25,3 \%)$.

Hasil penelitian Octavianty, dkk (2014) didapatkan dari 40 responden ibu rumah tangga, 20 responden $(50 \%)$ memiliki pengetahuan tinggi tentang HIV/AIDS dan 20 responden (50\%) memiliki pengetahuan rendah.

Data di atas mengindikasikan pentingnya pengetahuan tentang HIV/AIDS bagi perempuan. Perempuan, khususnya ibu rumah tangga harus turut aktif membekali diri dengan informasiinformasi seputar HIV/AIDS. Hal ini juga harus diikuti dengan peningkatan kepedulian lingkungan masyarakat melalui kegiatankegiatan penyuluhan untuk berbagi informasi mengenai HIV/AIDS seluas-luasnya secara rutin dan berkesinambungan yang tujuannya untuk mempersempit gerak penyebaran HIV/AIDS. (Kementerian Negara Pemberdayaan Perempuan RI, 2008)

Berdasarkan Keputusan Menteri Koordinator Kesejahteraan Rakyat RI No. 9 tahun 1994, yaitu salah satu sasaran komunikasi informasi dan edukasi (KIE) penanggulangan HIV/AIDS dan cara pemberian KIE pada kelompok berisiko tinggi. Informasi mengenai HIV/AIDS melalui media komunikasi tersebut dapat meningkatkan pengetahuan ibu rumah tangga yang beresiko tinggi menderita HIV/AIDS dan pengetahuan yang diterima diharapkan mampu mengubah sikap dan perilaku seks untuk mencegah HIV/AIDS (Juliastika, 2012).

Berdasarkan uraian di atas, maka penulis merasa perlu meneliti "Pengetahuan Ibu Rumah Tangga tentang HIV/AIDS di RT 01 RW 01 Dusun Pucung Lor Kecamatan Ngantru Kabupaten Tulungagung".

\section{Metode}

Penelitian ini merupakan penelitian deskriptif dengan pendekatan cross sectional. Populasi pada penelitian ini adalah seluruh ibu rumah tangga di RT 01 RW 01 Dusun Pucung Lor Kecamatan Ngantru Kabupaten Tulungagung. Sampel diambil dengan teknik accidental sampling hingga didapatkan sampel sejumlah 50 responden.

Penelitian dilakukan selama bulan Maret 2018 di RT 01 RW 01 Dusun Pucung Lor Kecamatan Ngantru Kabupaten Tulungagung.. Alat pengumpulan data yang digunakan adalah

141 | Jurnal Kebidanan Vol. 7, No. 2 Oktober 2018 
kuesioner yang sudah diuji validitas dan reliabilitas. Data yang terkumpul kemudian diolah melalui tahap editing, coding, scoring, tabulating. Analisis data menggunakan persentase.

\section{Hasil}

Dari hasil pengumpulan data, diperoleh karakteristik responden sebagai berikut:

Tabel 1. Karakteristik Responden

\begin{tabular}{lcc}
\hline \multicolumn{1}{c}{ Karakteristik Responden } & Frekuensi & Persentase (\%) \\
\hline Umur & & 0 \\
$\geq 20$ tahun & 0 & 8 \\
$21-25$ tahun & 4 & 6 \\
$26-30$ tahun & 3 & 26 \\
$31-35$ tahun & 13 & 60 \\
$>35$ tahun & 30 & \\
Tingkat Pendidikan & & 0 \\
Tidak Sekolah & 0 & 14 \\
SD & 7 & 52 \\
SMP & 26 & 34 \\
SMA & 17 & 0 \\
Perguruan Tinggi & 0 & 82 \\
Pekerjaan & & 18 \\
Tidak Bekerja & 41 & \\
Bekerja & 9 & \\
\hline
\end{tabular}

Berdasarkan tabel di atas, umur responden terentang dari umur 21 tahun sampai lebih dari 35 tahun. Sebagian besar responden berumur lebih dari 35 tahun, yaitu sebanyak 30 responden $(60 \%)$. Tingkat pendidikan responden $26(52 \%)$ adalah SMP. Menurut pekerjaan, mayoritas responden tidak bekerja, yaitu sebanyak 41 responden (82\%), hanya 9 responden (18\%) yang bekerja.

Tabel 2. Gambaran Pengetahuan Responden

\begin{tabular}{lcc}
\hline \multicolumn{1}{c}{ Kriteria Pengetahuan } & Frekuensi & Persentase $(\%)$ \\
\hline Baik & 0 & 0 \\
Cukup & 23 & 46 \\
Kurang & 27 & 54 \\
\hline Total & 50 & 100 \\
\hline
\end{tabular}

Berdasarkan tabel 2. dari 50 responden, 23 responden $(46 \%)$ memiliki pengetahuan yang cukup tentang HIV/AIDS. Responden dengan pengetahuan kurang sebayak 27 responden
(54\%). Dalam penelitian ini tidak ditemukan responden yang memiliki pengetahuan baik tentang HIV/AIDS. 
Aprilia Nurtika Sari : Pengetahuan Ibu Rumah Tangga Tentang HIV/ AIDS Di RT 01 RW 01

Dusun Pucung Lor Kecamatan Ngantru Kabupaten Tulungagung

Tabel 3. Gambaran Pengetahuan Berdasarkan Karakteristik Responden

\begin{tabular}{|c|c|c|c|c|}
\hline \multirow[b]{2}{*}{ Karakteristik } & \multicolumn{3}{|c|}{ Pengetahuan } & \multirow[b]{2}{*}{$\begin{array}{l}\text { Total } \\
\text { f }(\%)\end{array}$} \\
\hline & $\begin{array}{l}\text { Baik } \\
\text { f }(\%)\end{array}$ & $\begin{array}{c}\text { Cukup } \\
\text { f }(\%)\end{array}$ & $\begin{array}{c}\text { Kurang } \\
\text { f (\%) }\end{array}$ & \\
\hline \multicolumn{5}{|l|}{ Umur } \\
\hline$\leq 20$ tahun & 0 & 0 & 0 & 0 \\
\hline$\overline{2} 1-25$ tahun & 0 & $1(25 \%)$ & $3(75 \%)$ & $4(100 \%)$ \\
\hline 26-30 tahun & 0 & $2(66,67 \%)$ & $1(33,33 \%)$ & $3(100 \%)$ \\
\hline 31-35 tahun & 0 & $8(61,54 \%)$ & $5(38,46 \%)$ & $13(100 \%)$ \\
\hline$>35$ tahun & 0 & $12(40 \%)$ & $18(60 \%)$ & $30(100 \%)$ \\
\hline \multicolumn{5}{|l|}{ Tingkat Pendidikan } \\
\hline Tidak Sekolah & 0 & 0 & 0 & 0 \\
\hline SD & 0 & $1(14,29 \%)$ & $6(85,71 \%)$ & $7(100 \%)$ \\
\hline SMP & 0 & $14(53,85 \%)$ & $12(46,15 \%)$ & $26(100 \%)$ \\
\hline SMA & 0 & $8(47,06 \%)$ & $9(52,94 \%)$ & $17(100 \%)$ \\
\hline Perguruan Tinggi & 0 & 0 & 0 & 0 \\
\hline \multicolumn{5}{|l|}{ Pekerjaan } \\
\hline Tidak Bekerja & 0 & $20(48,78 \%)$ & $21(51,22 \%)$ & $41(100 \%)$ \\
\hline Bekerja & 0 & $3(33,33 \%)$ & $6(66,67 \%)$ & $9(100 \%)$ \\
\hline
\end{tabular}

Berdasarkan tabel 3. responden yang memiliki pengetahuan kurang tentang HIV/AIDS sebagian besar berusia lebih dari 35 tahun, yaitu sebanyak 18 responden (60\%). Berdasarkan tingkat pendidikan, sebagian besar responden dengan pengetahuan kurang memiliki tingkat pendidikan SMP, yaitu 12 responden $(46,15 \%)$. Berdasarkan pekerjaan, 21 responden $(51,22 \%)$ yang tidak bekerja memiliki pengetahuan yang kurang tentang HIV/AIDS.

\section{Diskusi}

Berdasarkan hasil penelitian, pengetahuan ibu rumah tangga tentang HIV/AIDS di RT 01 RW 01 Dusun Pucung Lor Kecamatan Ngantru Kabupaten Tulungagung termasuk kategori cukup, yaitu 23 responden (46\%), dan 27 responden (54\%) termasuk kategori kurang. Tidak ada responden yang berpengetahuan baik tentang HIV/AIDS.

Pengetahuan adalah kesan di dalam pikiran manusia sebagai hasil penggunaan pancaindranya. Pengetahuan adalah segala apa yangdiketahui berdasarkan pengalaman yang didapatkan oleh setiap manusia. Pengetahuan merupakan hasil mengingat suatu hal, termasuk mengingat kembali kejadian yang pernah dialami baik secara sengaja maupun tidak terhadap suatu objek tertentu (Mubarak, 2011: 8).

Seseorang akan memperoleh pengetahuan dari hasil penggunaan pancaindranya. Akan tetapi setiap orang memiliki daya ingat dan daya tangkap yang berbeda-beda. Berdasarkan hasil penelitian yang didapat dari kuesioner sebagian besar responden masih berpengetahuan kurang, yang artinya responden belum mengetahui apa itu HIV/AIDS, termasuk di dalamnya informasi

mengenai pengertian, penyebab, cara penularan dan gejala HIV/AIDS.

Hasil penelitian ini berbeda dengan penelitian yang dilakukan oleh Abhinaja \& Astuti (2014) di Kelurahan Sanur, Kecamatan Denpasar Selatan, Kota Denpasar yang menyatakan bahwa dari 87 responden, sebagian besar memiliki pengetahuan sedang sebanyak 47 responden $(54,02 \%)$. Hal ini mungkin disebabkan karena karakteristik responden di kedua tempat penelitian berbeda.

Dari tabel 3 diketahui bahwa sebagian besar responden yang memiliki pengetahuan kurang tentang HIV/AIDS sebagian besar tingkat pendidikannya adalah SMP, yaitu sebanyak 12 responden $(46,15 \%)$. Tidak ada responden yang memiliki latar pendidikan Perguruan Tinggi.

Pendidikan berarti bimbingan yang diberikan seseorang terhadap perkembangan orang lain menuju ke arah cita-cita tertentu. Pendidikan diperlukan untuk mendapat informasi, misalnya hal-hal yang menunjang kesehatan sehingga dapat meningkatkan kualitas hidup. Makin tinggi pendidikan seseorang makin

143 | Jurnal Kebidanan Vol. 7, No. 2 Oktober 2018 
mudah menerima informasi. (Wawan \& Dewi, 2010: 18).

Tingkat pengetahuan yang tinggi juga dipengaruhi oleh tingkat pendidikan. Semakin tinggi dan semakin formal tingkat pendidikan yang dimiliki seseorang maka semakin besar pula kegiatan yang bersifat intelek yang dilakukan. Responden yang memiliki pendidikan yang tinggi akan lebih banyak mendapatkan informasi dan pengalaman sehingga pengetahuan yang mereka dapatkan akan jauh lebih banyak (Sari \& Yusniati, 2018).

Pengetahuan responden tentang HIV/ AIDS yang masih kurang salah satunya disebabkan karena tingkat pendidikan sebagian besar responden adalah SMP. Tingkat pendidikan yang rendah menyebabkan keinginan responden untuk mencari informasi secara mandiri juga rendah. Tingkat pendidikan yang rendah juga dapat menyebabkan pengetahuan dan pemahaman yang keliru akan sebuah informasi, khususnya tentang HIV/AIDS.

Dari tabel 3 diketahui bahwa sebagian besar responden yang memiliki pengetahuan kurang tentang HIV/AIDS adalah ibu rumah tangga yang tidak bekerja, yaitu sebanyak 21 responden $(51,22 \%)$. Hanya $6(66,67 \%)$ responden yang merupakan ibu rumah tangga yang bekerja.

Menurut Markum (1991) dalam Agus (2009), manusia memerlukan suatu pekerjaan untuk dapat berkembang dan berubah. Seseorang bekerja bertujuan untuk mencapai suatu keadaan yang lebih dari pada keadaan sebelumnya. Dengan bekerja seseorang dapat berbuat yang bernilai, bermanfaat dan memperoleh berbagai pengalaman.

Oleh sebab itu pekerjaan juga merupakan faktor yang mempengaruhi pengetahuan seseorang. Dengan bekerja seseorang dapat mengenal situasi sosial yang berbeda-beda, berhadapan dengan individu yang berbeda pula, serta mempunyai banyak akses dalam memperoleh informasi dan pengalaman baru.

Ibu rumah tangga yang tidak bekerja mempunyai akses yang terbatas dalam memperoleh informasi. Sehingga diperlukan peran aktif dari petugas kesehatan untuk memberikan penyuluhan melalui kegiatankegiatan di masyarakat yang banyak diikuti oleh ibu rumah tangga. Kegiatan tersebut diantaranya yaitu pengajian, arisan, dan posyandu.

Responden yang memiliki pengetahuan dan pemahaman yang tepat dan benar akan memberikan tanggapan positif terhadap suatu hal yang mereka ketahui (Sari \& Soraya, 2017). Responden yang memiliki pemahaman yang tepat tentang HIV/AIDS akan dapat menambah pengetahuan tentang HIV/AIDS, sehingga responden dapat menyikapi penyakit HIV/AIDS dengan positif.

Perempuan adalah kelompok yang rentan terinfeksi HIV/AIDS karena secara biologis, mereka lebih mudah tertular penyakit-penyakit melalui hubungan seksual dibanding laki-laki. Perempuan memiliki mukosa vagina yang lebih luas sehingga cairan sperma mudah terpapar ketika hubungan seksual. Akan tetapi, kerentanan perempuan akan HIV/AIDS tidak diikuti dengan kemudahan akses informasi dan pendidikan. Akses informasi dan pendidikan perempuan jauh lebih rendah sehingga mereka tidak memiliki pengetahuan yang cukup mengenai kesehatan reproduksi, termasuk persoalan seputar HIV/AIDS dan pelayanan kesehatan yang menjadi hak mereka. (Dalimoenthe, 2011)

Dalam menghadapi permasalahan tersebut, perempuan harus membekali dirinya dengan pengetahuan yang tepat dan benar tentang bahaya dan cara penularan HIV/AIDS. Selain dalam bentuk upaya secara individual, juga perlu didukung dengan upaya yang bersifat kelembagaan. Hal ini akan memberikan sumbangan yang berarti terhadap upaya penanggulangan HIV/AIDS secara sistemik dan harus dilakukan secara terus-menerus dan konsisten.

\section{Simpulan}

Hasil penelitian menunjukkan bahwa masih banyak ibu rumah tangga yang mempunyai pengetahuan kurang tentang HIV/AIDS. Oleh karena itu petugas kesehatan harus memaksimalkan upaya dalam memberikan penyuluhan - penyuluhan kesehatan kepada ibu rumah tangga, khususnya informasi mengenai HIV/AIDS.

\section{Daftar Pustaka}

Abhinaja, I.G.W., Astuti, P.A.S. 2013. Pengetahuan, Sikap Ibu Rumah Tangga Mengenai Infeksi Menular Seksual Termasuk HIV/AIDS Serta Perilaku Pencegahannya Di Kelurahan Sanur, Kecamatan Denpasar Selatan, Kota Denpasar Tahun. 2013. Community Health. 1 (3): 218-228 
Aprilia Nurtika Sari : Pengetahuan Ibu Rumah Tangga Tentang HIV/ AIDS Di RT 01 RW 01 Dusun Pucung Lor Kecamatan Ngantru Kabupaten Tulungagung

Dalimoenthe, Ikhlasiah. 2011. Perempuan dalam Cengkeraman HIV/AIDS: Kajian Sosiologi Feminis Perempuan Ibu Rumah Tangga. Komunitas. 5 (1): 41-48

Juliastika, et al. 2012. Hubungan pengetahuan tentang HIV/AIDS dengan sikap dan tindakan penggunaan kondom pria pada wanita pekerja seks di Kota Manado. Ejournal Universitas Sam Ratulangi Manado; 1 (1): 15 - 20

Kementerian Kesehatan RI. 2014. Situasi dan Analisis HIV-AIDS. Jakarta: Pusdatin Kemenkes RI

Kementerian Kesehatan RI. 2018. Situasi Umum HIV/AIDS dan Tes HIV. Jakarta: Pusdatin Kemenkes RI

Kementerian Negara Pemberdayaan Perempuan RI. 2008. Pemberdayaan Perempuan dalam Pencegahan Penyebaran HIV-AIDS. Jakarta : Kementerian Negara Pemberdayaan Perempuan RI

Mubarak, Wahit Iqbal. 2011. Promosi Kesehatan Untuk Kebidanan. Jakarta: Salemba Medika

UNAIDS. 2018. Fact sheet - Latest statistics on the status of the AIDS epidemic. Retrieved from http://www.unaids.org/ en/resources/fact-sheet

Sari, A.N., Soraya, R. 2017. Perbedaan Pengetahuan Ibu Hamil Tentang Pencegahan Penularan Human Immunodeficiency Virus (HIV) Dari Ibu Ke Anak (PPIA) Sebelum dan Sesudah Diberi Penyuluhan (Desa Gampeng Kecamatan
Gampengrejo Kabupaten Kediri). Jurnal Kebidanan Dharma Husada. 6 (2): 620-625

Sari, A.N., Yusniati, L. 2018. Interest of The Pregnant Women In Doing Examination The Voluntary Counselling And Testing (VCT) (In Ngronggo Village In The Central District of Kediri). IJNER. 1 (1): -

Wawan, A \& M. Dewi. 2010. Pengetahuan, Sikap, dan Perilaku Manusia. Yogyakarta: Nuha Medika 